\title{
PEMBENTUKAN NILAI KARAKTER INTEGRITAS MELALUI GERAKAN LITERASI SEKOLAH PADA ANAK MI/SD
}

\author{
${ }^{1)}$ Vita Fitriatul Ulya, IAI Al Hikmah Tuban, email: vitaf3@gmail.com \\ ${ }^{2)}$ Zulfatun Anisah, IAI Al Hikmah Tuban, email: zulfatun.anisah.alhikmahtuban@ gmail.com
}

\begin{abstract}
The character of integrity is one of the main character values in the Movement for Strengthening Character Education launched by the Ministry of Education and Culture in 2016. The character values in question include religious, nationalist, mutual cooperation, independence and integrity. These character values need to be instilled from childhood. Likewise, the character of integrity can be formed through formal education in elementary schools, one of which is through literacy programs. Elementary school level children have the characteristics of high curiosity and understand concrete things better than abstract. So that the literacy program that is applied must be interesting and fun. The literacy program has developed dynamically, which was initially only defined as the ability to read and write, then developed with the ability to think critically and speak spoken language. One form of literacy in schools is through the School Literacy Movement. One form of literacy at school is through the habit of reading books other than textbooks for 15 minutes before the lesson begins. Books that contain exemplary stories can shape children's morals. In addition, the provision of training from the teacher can train children's honesty. Giving assignments also trains children's responsibilities. It is hoped that through the literacy program, children's integrity character is formed, including honesty, love for the truth, loyalty, moral commitment, anti-corruption, justice, responsibility, example, respecting individual differences.
\end{abstract}

Keywords : Formation, integrity character values, and school literacy movement

\section{Pendahuluan}

Gerakan Nasional Pendidikan Karakter secara intensif sudah dimulai sejak tahun 2010. Kementerian Pendidikan Nasional pada tahun 2010 mengeluarkan Rencana Aksi Nasional (RAN) Pendidikan Karakter untuk mengembangkan rintisan di sekolah-sekolah seluruh Indonesia dengan 18 nilai karakter. Nilai karakter tersebut antara lain religius, jujur, toleransi, disiplin, kerja keras, kreatif, mandiri, demokratis, rasa ingin tahu, semangat kebangsaan, cinta tanah air, menghargai prestasi, komunikatif, cinta damai, gemar membaca, peduli sosial dan tanggung jawab. ${ }^{1}$ Gerakan Nasional Pendidikan Karakter yang dimulai pada tahun 2010 ini sudah melahirkan sekolah-sekolah rintisan yang mampu melaksanakan pembentukan karakter secara kontekstual sesuai dengan potensi lingkungan setempat.

\footnotetext{
${ }^{1}$ Said Hamid Hasan, dkk., Pengembangan Pendidikan Budaya dan Karakter Bangsa (Jakarta: Puskur Balitbang Kemendiknas, 2010), 8
} 
Selanjutnya pada tahun 2016, dilaksanakan Gerakan Penguatan Pendidikan Karakter (PPK) dengan mengindahkan asas keberlanjutan dan kesinambungan. Gerakan PPK berupaya mengintegrasikan, memperdalam, memperluas, dan sekaligus menyelaraskan berbagai program dan kegiatan pendidikan karakter yang sudah dilaksanakan. Dalam hal ini, pengintegrasian dapat berupa pemaduan kegiatan kelas, luar kelas di sekolah, dan luar sekolah (masyarakat/komunitas); pemaduan kegiatan intrakurikuler, kokurikuler, dan ekstrakurikuler; pelibatan secara serempak warga sekolah, keluarga, dan masyarakat; perdalaman dan perluasan dapat berupa penambahan dan pengintensifan kegiatan-kegiatan yang berorientasi pada pengebangan karakter siswa, penambahan dan pemajangan kegiatan belajar siswa, dan pengaturan ulang waktu belajar siswa di sekolah atau luar sekolah; kemudian penyelerasan dapat berupa penyesuaian tugas pokok guru, Manajemen Berbasis Sekolah, dan fungsi Komite Sekolah dengan kebutuhan Gerakan PPK. Dalam Gerakan PPK terdapat nilai karakter utama yaitu religius, nasionalis, mandiri, gotong royong dan integritas. ${ }^{2}$

Karakter integritas merupakan salah satu nilai karakter utama yang ada pada Gerakan PPK. Integritas merupakan hal yang penting karena mencerminkan kualitas kejujuran seseorang dan prinsip moral, yang dilakukan secara konsisten dalam penyelenggaraan kehidupannya. Seseorang dikatakan berintegritas apabila memiliki konsistensi antara apa yang dikatakan dan yang diperbuat, dan perbuatannya itu sesuai dengan nilai-nilai yang ada dalam masyarakat.

Terkait hal di atas, banyak pihak yang berpendapat bahwa sekolah dasar merupakan wadah utama pembentukan karakter. Pembelajaran di sekolah dasar merupakan fondasi pendidikan yang efektif dalam pembentukan watak dan kepribadian, sehingga dalam pembelajaran di sekolah dasar tersebut cocok ditanamkan nilai integritas. Salah satu strategi dalam penanaman integritas adalah melalui gerakan literasi sekolah. Gerakan literasi di sekolah tidak hanya sekedar kegiatan membaca dan menulis saja, akan tetapi juga mencakup ketrampilan berpikir menggunakan sumber-sumber pengetahuan baik dalam bentuk cetak, visual, digital maupun auditori. Kemampuan tersebut termasuk dalam literasi informasi. Menurut Ferguson ada 5 macam literasi informasi, yaitu literasi dasar, literasi perpustakaan, literasi media, literasi tekonologi dan literasi visual. ${ }^{3}$

\footnotetext{
${ }^{2}$ Kementrian Pendidikan dan Kebudayaan Republik Indonesia, Kajian dan Pedoman Penguatan Pendidikan Karakter, 7-8

3 Ferguson B., Information Literacy. A Primer for Teachers, Librarians, and Other Informed People (www.bibliotech.us/pdfs/InfoLit.pdf, diakses pada 28 Desember 2019).
} 
Meskipun dikatakan sebagai wadah utama pembentukan karakter, jenjang pendidikan sekolah dasar merupakan masa transisi dari masa bermain di pendidikan anak usia dini (taman kanak-kanak akhir) memasuki lingkungan sekolah formal. Peran lembaga pendidikan bukan hanya sekedar transfer of knowledge antara pendidik dan peserta didik yang berlangsung dalam suasana edukatif, tetapi ada kemampuan yang harus dikembangkan dalam setiap proses pembelajaran peserta didik di sekolah. ${ }^{4}$ Jadi sebisa mungkin metode yang diterapkan guru dalam membentuk karakter anak harus menyenangkan dan tidak membosankan. Dalam hal ini, karakter integritas yang dibentuk melalui program literasi bisa dilakukan dengan cara misalnya siswa diajak membaca buku cerita bergambar yang di dalamnya bisa dipetik pelajaran moralnya. Contoh lain misalnya guru mengadakan tanya jawab melalui metode enjoyfull learning dan siswa dituntut untuk menjawab pertanyaan yang ada. Ini bertujuan untuk melatih sportivitas siswa dan kejujuran siswa dalam menjawab setiap soal. Dan masih banyak lagi metode-metode pembentukan karakter integritas siswa tingkat sekolah dasar yang dilakukan melalui program literasi.

\section{Metodologi}

Penulisan artikel ilmiah harus dilakukan penyusunan yang sistematis untuk memudahkan pemahaman pembaca. Salah satunya menggunakan penelitian studi pustaka. Artikel ini menggunakan teknik studi literatur atau kajian pustaka. Berbagai buku, jurnal, dan laporan penelitian yang berkaitan dengan kajian "pembentukan nilai karakter integritas melalui gerakan literasi sekolah pada anak MI/SD”. Teknik ini bertujuan untuk mengungkapkan berbagai teoriteori yang relevan dengan permasalahan yang sedang diteliti sebagai bahan rujukan dalam pembahasan hasil penelitian. Informasi-informasi penting yang ditemukan dalam sumber, dicatat dan diolah guna manjawab topik pembahasan, sehingga menghasilkan tulisan yang utuh dan sistematis.

Pemilihan sumber referensi menjadi langkah awal, supaya tendensi yang dipakai dapat dipertanggungjawabkan kebenarannya (bersifat ilmiah). Analisis yang tajam dan kritis dapat membantu penyajian data yang komprehensif. Langkah selanjutnya yakni mengolah informasi

\footnotetext{
${ }^{4}$ Akhmad Aji Pradana, \& Jazilatul Ummah. (2020). PENGARUH MEDIA SEMPOA TERHADAP KEMAMPUAN OPERASI HITUNG PENGURANGAN SISWA KELAS II MI . PREMIERE : Journal of Islamic Elementary Education, 2(1), 94-102. https://doi.org/10.51675/jp.v2i1.89
} 
menjadi kalimat-kalimat yang penempatanya sesuai fokus bahasan. Kalimat diuraikan secara detail dan terperinci agar diperoleh tulisan yang utuh dan lengkap.

\section{Hasil}

\section{Nilai-nilai Karakter menurut Gerakan PPK}

Seperti yang telah disebutkan di atas, pada tahun 2010 telah dirumuskan nilai-nilai karakter sebagai grand design untuk setiap jalur, jenjang, dan jenis satuan pendidikan. Nilainilai yang dikembangkan dalam pendidikan budaya dan karakter bangsa didasarkan kepada empat dasar yang menjadi landasannya, yaitu agama, pancasila, budaya dan tujuan pendidikan nasional. ${ }^{5}$ Berdasarkan keempat sumber nilai itu, teridentifikasi sejumlah nilai untuk pendidikan budaya dan karakter bangsa sebagai berikut. ${ }^{6}$

\section{Tabel 2.2}

Nilai dan Deskripsi Nilai Pendidikan Budaya dan Karakter Bangsa menurut Dinas

Pendidikan

\begin{tabular}{|c|l|}
\hline Nilai & \multicolumn{1}{|c|}{ Deskripsi } \\
\hline Religius & $\begin{array}{l}\text { Sikap dan perilaku yang patuh dalam melaksanakan } \\
\text { ajaran agama yang dianutnya, toleran terhadap } \\
\text { pelaksanaan ibadah agama lain, dan hidup rukun } \\
\text { dengan pemeluk agama lain. }\end{array}$ \\
\hline Jujur & $\begin{array}{l}\text { Perilaku yang didasarkan pada upaya menjadikan } \\
\text { dirinya sebagai orang yang selalu dapat dipercaya. }\end{array}$ \\
\hline Toleransi & $\begin{array}{l}\text { Sikap dan tindakan yang menghargai perbedaan } \\
\text { agama, suku, pendapat, dan tindakan orang lain } \\
\text { yang berbeda dari dirinya. }\end{array}$ \\
\hline Disiplin & $\begin{array}{l}\text { Tindakan yang menunjukkan perilaku tertib dan } \\
\text { patuh pada berbagai ketentuan dan peraturan. }\end{array}$ \\
\hline Kerja keras & $\begin{array}{l}\text { Perilaku yang menunjukkan upaya sungguh- } \\
\text { sungguh dalam mengatasi berbagai hambatan } \\
\text { belajar dan tugas, dan menyelesaikan tugas dengan } \\
\text { sebaik-baiknya. }\end{array}$ \\
\hline Kreatif & $\begin{array}{l}\text { Berpikir dan melakukan sesuatu untuk } \\
\text { menghasilkan cara atau hasil baru dari sesuatu yang } \\
\text { telah dimiliki. }\end{array}$ \\
\hline
\end{tabular}

${ }^{5}$ Kementrian Pendidikan Nasional, Bahan Pelatihan, Penguatan Metodologi Pembelajaran Berdasarkan Nilai-nilai Budaya untuk Membentuk Daya Saing dan Karakter Bangsa, (Jakarta: Kementrian Pendidikan Nasional, 2010), 8.

${ }^{6}$ Ibid., 9-10. Lihat. Said Hamid Hasan, dkk., Pengembangan Pendidikan Budaya dan Karakter Bangsa (Jakarta: Puskur Balitbang Kemendiknas, 2010), 8. 


\begin{tabular}{|c|l|}
\hline Mandiri & $\begin{array}{l}\text { Sikap yang tidak mudah tergantung pada orang lain } \\
\text { dalam meyelesaikan tugas-tugasnya. }\end{array}$ \\
\hline Demokratis & $\begin{array}{l}\text { Cara berpikir, bersikap, dan bertindak yang menilai } \\
\text { sama hak dan kewajiban dirinya dan orang lain. }\end{array}$ \\
\hline $\begin{array}{c}\text { Rasa Ingin } \\
\text { Tahu }\end{array}$ & $\begin{array}{l}\text { Sikap yang selalu berupaya untuk mengetahui lebih } \\
\text { mendalam dari sesuatu yang dipelajarinya. }\end{array}$ \\
\hline $\begin{array}{c}\text { Semangat } \\
\text { Kebangsaan }\end{array}$ & $\begin{array}{l}\text { Cara bertindak yang menempatkan kepentingan } \\
\text { negara diatas kepentingan diri dan kelompok. }\end{array}$ \\
\hline $\begin{array}{c}\text { Cinta Tanah } \\
\text { Air }\end{array}$ & $\begin{array}{l}\text { Cara bersikap yang menunjukkan kesetiaan, } \\
\text { kepedulian, dan penghargaan yang tinggi terhadap } \\
\text { bahasa, sosial, budaya, ekonomi dan politik bangsa. }\end{array}$ \\
\hline $\begin{array}{c}\text { Menghargai } \\
\text { Prestasi }\end{array}$ & $\begin{array}{l}\text { Sikap dan tindakan yang mendorong dirinya untuk } \\
\text { menghasilkan sesuatu yang berguna bagi } \\
\text { masyarakat, dan mengakui keberhasilan orang lain. }\end{array}$ \\
\hline Komunikatif & $\begin{array}{l}\text { Tindakan yang memperlihatkan rasa senang } \\
\text { berbicara, bergaul, dan bekerja sama dengan orang } \\
\text { lain. }\end{array}$ \\
\hline Cinta Damai & $\begin{array}{l}\text { Sikap, perkataan, dan tindakan yang menyebabkan } \\
\text { orang lain merasa senang dan aman atas kehadiran } \\
\text { dirinya. }\end{array}$ \\
\hline $\begin{array}{c}\text { Gemar } \\
\text { Membaca }\end{array}$ & $\begin{array}{l}\text { Kebiasan menyediakan waktu untuk membeca } \\
\text { berbagai bacaan yang memberikan kebajikan bagi } \\
\text { dirinya. }\end{array}$ \\
\hline $\begin{array}{c}\text { Peduli } \\
\text { Sosial }\end{array}$ & $\begin{array}{l}\text { Sikap dan tindakan yang selalu ingin memberi } \\
\text { bantuan kepada orang lain dan masyarakat yang } \\
\text { membutuhkan. }\end{array}$ \\
\hline Tanggung & $\begin{array}{l}\text { Sikap dan perilaku seseorang untuk melaksanakan } \\
\text { tugas dan kewajibannya, yang seharusnya } \\
\text { dilakukan terhadap diri sendiri, masyarakat, } \\
\text { lingkungan (alam, sosial, dan budaya), negara, dan } \\
\text { Tuhan Yang Maha Esa. }\end{array}$ \\
\hline
\end{tabular}

Nilai karakter di atas adalah yang dikeluarkan Kementrian Pendidikan Nasional pada tahun 2010 untuk mengembangkan pendidikan nasional. Selanjutnya pada tahun 2016 dikembangkan Gerakan Penguatan Pendidikan Karakter (PPK) oleh Kemendikbud. Dalam hubungan ini Gerakan PPK menempatkan nilai karakter sebagai dimensi terdalam pendidikan yang membudayakan dan memberadabkan. Untuk itu, ada 5 nilai utama karakter yang saling berkaitan membentuk jejaring nilai karakter yang perlu dikembangkan. Kelima nilai utama karakter bangsa yang dimaksud adalah sebagai berikut. $^{7}$

\footnotetext{
${ }^{7}$ Kementrian Pendidikan dan Kebudayaan Republik Indonesia, Kajian dan Pedoman Penguatan Pendidikan
} Karakter, 7-8. 


\section{1) Nilai karakter religius}

Nilai karakter ini mencerminkan keberimanan kepada Tuhan yang Maha Esa yang diwujudkan dalam perilaku untuk melaksanakan ajaran agama dan kepercayaan yang dianut, menghargai perbedaan agama, menjunjung tinggi sikap toleran terhadap pelaksanaan ibadah agama dan kepercayaan lain, hidup rukun dan damai dengan pemeluk agama lain. Nilai karakter religius ini meliputi tiga dimensi relasi sekaligus, yaitu hubungan individu dengan Tuhan, individu dengan sesama, dan individu dengan alam semesta (lingkungan).

Nilai karakter religius ini ditunjukkan dalam perilaku mencintai dan menjaga keutuhan ciptaan. Nilai religius yang dimaksud meliputi cinta damai, toleransi, menghargai perbedaan agama, teguh pendirian, percaya diri, kerja sama lintas agama, anti kekerasan, persahabatan, ketulusan, tidak memaksakan kehendak, melindungi yang kecil dan tersisih.

\section{2) Nilai karakter nasionalis}

Nilai karakter nasionalis merupakan cara berpikir, bersikap, dan berbuat yang menunjukkan kesetiaan, kepedulian, dan penghargaan yang tinggi terhadap bahasa, lingkungan fisik, sosial, budaya, ekonomi, dan politik bangsa, menempatkan kepentingan diri dan kelompoknya.

Subnilai nasionalis antara lain apresiasi budaya bangsa sendiri, menjaga kekayaan budaya bangsa, rela berkorban, unggul dan berprestasi, cinta tanah air, menjaga lingkungan, taat hukum, disiplin, menghormati keragaman budaya, suku dan agama.

\section{3) Nilai karakter mandiri}

Nilai karakter mandiri merupakan sikap dan perilaku tidak bergantung pada orang lain dan mempergunakan segala tenaga, pikiran, waktu untuk merealisasikan harapan, mimpi dan cita-cita.

Subnilai kemandirian antara lain etos kerja (kerja keras), tangguh tahan banting, daya juang, profesional, kreatif, keberanian, dan menjadi pembelajar sepanjang hayat.

\section{4) Nilai karakter gotong royong}

Nilai karakter gotong royong mencerminkan tindakan menghargai semangat kerja sama dan bahu membahu menyelesaikan persoalan bersama, memperlihatkan rasa senang berbicara, bergaul, bersahabat dengan orang lain dan memberi bantuan pada mereka yang miskin, tersingkir dan membutuhkan pertolongan. Subnilai gotong royong antara lain menghargai, kerja sama, inklusif, komitmen atas keputusan bersama, musyawarah mufakat, 
tolong-menolong, solidaritas, empati, anti diskriminasi, anti kekerasan, dan sikap kerelawanan.

\section{5) Nilai karakter integritas}

Nilai karakter integritas merupakan nilai yang mendasari perilaku yang didasarkan pada upaya menjadikan dirinya sebagai orang yang selalu dapat dipercaya dalam perkataan, tindakan, dan pekerjaan, memiliki komitmen dan kesetiaan pada nilai-nilai kemanusiaan dan moral (integritas moral). Karakter integritas meliputi sikap tanggungjawab sebagai warga negara, aktif terlibat dalam kehidupan sosial, melalui konsistensi tindakan dan perkataan yang berdasarkan kebenaran. Subnilai integritas antara lain kejujuran, cinta pada kebenaran, setia, komitmen moral, anti korupsi, keadilan, tanggungjawab, keteladanan, menghargai martabat individu (terutama penyandang disabilitas).

\section{Konsep Nilai Karakter Integritas}

Kata “integritas" berasal dari Bahasa Latin, yaitu "integer” yang mengandung arti:

1. Keteguhan sikap dalam mempertahankan prinsip yang menjadi landasan hidup dan melekat pada diri seseorang sebagai nilai-nilai moral.

2. Mutu, sifat, atau keadaan yang menunjukkan kesatuan yang utuh sehingga memiliki potensi dan kemampuan yang memancarkan kewibawaan; kejujuran. ${ }^{8}$

Integritas merupakan hal yang penting yang harus dimiliki oleh setiap individu. Hal ini karena integritas mencakup konsistensi dalam tindakan-tindakan, nilai-nilai, prinsip-prinsip dan berbagai hal lain yang dilakukan dalam kehidupan sehari-hari. Orang yang berintegritas mengatakan kebenaran dan bertanggung jawab atas perbuatan yang dilakukannya.

Dari penjelasan tersebut maka dapat disimpulkan bahwa integritas adalah jati diri seseorang dan merupakan lawan langsung dari kemunafikan. Secara umum, arti integritas adalah kualitas kejujuran dan prinsip moral di dalam diri seseorang yang dilakukan secara konsisten dalam kehidupannya secara menyeluruh. Pengertian integritas adalah suatu kepribadian seseorang yang bertindak secara konsisten dan utuh, baik dalam perkataan maupun perbuatan, sesuai dengan nilai-nilai dan kode etik. Seseorang dianggap berintegritas ketika ia memiliki kepribadian dan karakter berikut:

${ }^{8}$ www.maxmanroe.com/vid/umum/arti-integritas-adalah.html. Lihat juga pada Kamus Besar Bahasa Indonesia (KBBI) online http://kbbi.web.id/integritas.html. Diakses pada 29 Desember 2019. 
1. Jujur dan dapat dipercaya

2. Memiliki komitmen

3. Bertanggung jawab

4. Menepati ucapannya

5. Setia

6. Menghargai waktu

7. Memiliki prinsip dan nilai-nilai hidup ${ }^{9}$

Dalam gerakan Penguatan Pendidikan Karakter (PPK) yang dirumuskan Kemendikbud, integrasi sendiri meliputi sikap kejujuran, yakni dapat dipercaya dalam perkataan dan perbuatan, sikap tanggung jawab sebagai warga negara dan adanya komitmen dalam menjunjung tinggi nilai-nilai kemanusiaan dan moralitas. ${ }^{10}$

Proses pendidikan yang profesional dapat membentuk karakter peserta didik. Karakter dapat dimiliki apabila kita memiliki integritas. Menurut McCain, integritas adalah kesetiaan pada nurani dan kejujuran pada diri sendiri sehingga akan membentuk karakter. ${ }^{11}$ Karena itu, inti dari integritas adalah kejujuran pada diri sendiri maupun kepada orang lain. Masih menurut McCain bahwa prinsip tersebut merupakan harta milik yang terpenting. Bukan penampilan, kemampuan, bakat, kenyamanan atau kenikmatan, pekerjaan, rumah, mobil, mainan, berapa banyak teman yang mereka miliki, atau berapa banyak uang yang mereka hasilkan, namun kejujuran merupakan harta yang tidak ternilai dapat memberikan ketenangan hidup. Oleh karena itu, McCain dalam bukunya "Karakter-Karakter yang Menggugah Dunia" mengisahkan individu yang memiliki karakter istimewa yang membawa hidup dan dunia mereka lebih baik. Karakter tersebut membawa keteguhan dalam menjalani kehidupan yang penuh tantangan, penuh semangat yang tinggi dan tidak mengenal lelah untuk mencapai cita-cita.

\footnotetext{
9 www.maxmanroe.com/vid/umum/arti-integritas-adalah.html. Diakses pada 29 Desember 2019.

${ }^{10}$ Kementrian Pendidikan, Kajian dan Pedoman..., 8

${ }^{11}$ McCain, John \& Mark Salter, Karakter-Karakter yang Menggugah Dunia, Terj. T. Hermaya (Jakarta: Gramedia Pustaka Utama, 2009), 50-53
} 


\section{Gerakan Literasi Sekolah}

Kata literasi merupakan bentuk serapan dari bahasa Inggris letter yang berarti aksara atau tulisan. Menurut JP. Chaplin literasi adalah kemampuan dalam membaca dan menulis, serta memiliki kemampuan banyak dalam bidang tertentu. ${ }^{12}$

Makna literasi berkembang secara dinamis. Yang awalnya hanya diartikan sebagai kemampuan membaca dan menulis, kemudian berkembang disertai kemampuan dalam berpikir kritis dan berbahasa lisan. Literasi juga tidak hanya dilakukan di rumah saja, akan tetapi juga di sekolah dan lingkungan masyarakat. ${ }^{13}$ Adapun salah satu bentuk literasi di sekolah adalah melalui Gerakan Literasi Sekolah atau yang biasa disingkat dengan GLS.

Gerakan literasi sekolah (GLS) adalah salah satu upaya Kementerian Pendidikan dan Kebudayaan dalam mencapai salah satu dari sembilan agenda prioritas (Nawacita) yaitu melakukan revolusi karakter bangsa. Gerakan literasi khususnya di Sekolah Dasar memiliki tujuan dalam menciptakan lingkungan pendidikan di sekolah dasar yang literat yaitu menyenangkan dan ramah peserta didik sehingga menumbuhkan semangat belajar, menunjukkan empati, peduli dan menghargai sesama, menumbuhkan semangat ingin tahu dan cinta pengetahuan, cakap berkomunikasi dan dapat berkontribusi kepada lingkungan sosialnya, dan mengakomodasi partisipasi seluruh warga sekolah dan lingkungan eksternal sekolah.

Gerakan Literasi Sekolah (GLS) dikembangkan berdasarkan Permendikbud Nomor 23 Tahun 2015 tentang Penumbuhan Budi Pekerti. Kegiatan literasi selama ini hanya identik dengan aktivitas membaca dan menulis saja, padahal pengertian literasi sekolah dalam konteks Gerakan Literasi Sekolah meliputi kemampuan mengakses, memahami, dan menggunakan sesuatu secara cerdas melalui berbagai aktivitas, antara lain membaca, melihat, menyimak, menulis, dan/atau berbicara. Gerakan Literasi Sekolah merupakan suatu usaha atau kegiatan yang bersifat partisipatif dengan melibatkan warga sekolah (peserta didik, guru, kepala sekolah, tenaga kependidikan, pengawas sekolah, komite sekolah, orang tua/wali

\footnotetext{
${ }_{12}^{12}$ James P. Chaplin, Kamus Lengkap Psikologi (Jakarta: PT Grafindo Persada, 1993), 279.

13 Suyono, Pengembangan Perilaku Berliterasi Siswa Berbasis Kegiatan Ilmiah: Hasil-hasil Penelitian dan Implementasinya di Sekolah, Jurnal Ilmu Pendidikan, Jilid 3, Nomor 2, Juni 2006, 81-90
} 
murid peserta didik), akademisi, penerbit, media massa, masyarakat, dan pemangku kepentingan. ${ }^{14}$

Kegiatan gerakan literasi sekolah merupakan upaya menumbuhkan kecintaan membaca kepada peserta didik dan pengalaman belajar yang menyenangkan sekaligus merangsang imajinasi. Dalam aplikasi Gerakan Literasi Sekolah, para pemangku kepentingan perlu dilibatkan secara terprogram dengan tujuan agar peserta didik, terutama di tingkat pendidikan dasar, menjadi insan berbudaya literasi.

Melalui penguatan kompetensi literasi, terutama literasi dasar, diharapkan seluruh peserta didik dapat memanfaatkan akses lebih luas pada pengetahuan, sehingga tinggi rendahnya peringkat kompetensi dapat diketahui dan dilakukan perbaikan pada peringkat kompetensi yang rendah. Dengan demikian, dengan bekal kompetensi literasi peserta didik memiliki tingkat pengetahuan yang luas sekaligus memiliki konsistensi terhadap perilakunya. Hal ini menunjukkan bahwa tingkat integritas seseorang dapat diwujudkan melalui program literasi di sekolah.

\section{Implementasi Nilai Karakter Integritas melalui Gerakan Literasi Anak SD/MI}

Gerakan literasi adalah kegiatan mengasah kemampuan dalam memahami, mengolah, dan memanfaatkan informasi secara kritis dan cerdas melalui kegiatan membaca, menulis, menyimak dan berbicara untuk menumbuhkembangkan karakter seseorang menjadi tangguh, kuat, dan baik.

Kegiatan literasi dapat diintegrasikan ke dalam kegiatan pembelajaran dan mata pelajaran yang ada di struktur kurikulum. Dalam kegiatan mengajar, guru dapat mengajak siswanya untuk membaca, menulis, menyimak, dan bahkan berbicara (seperti pidato dan presentasi) dengan cermat dan tepat tentang suatu tema atau topik yang ada di berbagai sumber baik buku, surat kabar, media sosial dan sumber-sumber yang lain.

Dalam hubungan ini diperlukan ketersediaan sumber-sumber informasi di sekolah, antara lain buku, surat kabar, dan jejaring internet. Oleh sebab itu, keberadaan dan peranan pojok buku, perpustakaan sekolah, dan jaringan internet demikian penting. Di samping itu, sangat penting kreativitas guru dalam menyajikan program dan kegiatan membaca, menulis,

${ }^{14}$ Direktorat Jenderal Pendidikan Dasar dan Menengah Kementrian Pendidikan dan Kebudayaan, Desain Induk Gerakan Literasi Sekolah (Jakarta: Direktorat Jenderal Pendidikan Dasar dan Menengah Kementrian Pendidikan dan Kebudayaan, 2016), 7-8. 
menyimak, dan berbicara secara cerdas supaya peserta didik dapat melakukan pembatinan dan pembiasaan diri. Salah satu gerakan literasi yang bisa dikembangkan adalah Gerakan Membaca 15 Menit sebelum pelajaran dimulai. ${ }^{15}$

Penanaman nilai karakter integritas melalui literasi ini sudah selayaknya ditanamkan sejak pendidikan dasar, lalu dilanjutkan pada jenjang pendidikan yang lebih tinggi, agar peserta didik dapat meningkatkan kemampuan untuk mengakses informasi dan pengetahuan. Selain itu, peserta didik mampu membedakan informasi yang bermanfaat dan tidak bermanfaat. Hal itu karena literasi mengarahkan seseorang pada kemampuan memahami pesan yang diwujudkan dalam berbagai bentuk teks (lisan, tulis, visual).

Program GLS dilaksanakan secara bertahap dengan mempertimbangkan kesiapan sekolah di seluruh Indonesia. Pembiasaan untuk mengembangkan GLS adalah pembiasaan kegiatan membaca yang menyenangkan di ekosistem sekolah. Kegiatan yang dapat dilakukan adalah lima belas menit membaca setiap hari sebelum jam pelajaran melalui kegiatan membacakan buku dengan nyaring(read aloud) atau seluruh warga sekolah membaca dalam hati (sustained silent reading). Lingkungan sekolah menyediakan perpustakaan sekolah, sudut baca, area baca yang nyaman, sarana yang lain, dan penyediaan koleksi teks cetak, visual, digital yang mudah diakses oleh seluruh warga sekolah. Kegiatan ini dikemas dalam suasana yang menyenangkan tanpa tagihan. Kalau kegiatan ini sudah berjalan dengan baik, baru dilanjutkan tahap kedua, pengembangan minat baca untuk meningkatkan kemampuan literasi yang berupa pengembangan dengan tagihan sederhana untuk penilaian nonakademik. Tahap ketiga adalah pelaksanaan pembelajaran berbasis literasi yang berupa pembelajaran dengan adanya tagihan akademik. Pelaksanaan pembelajaran berbasis literasi di atas bertujuan mengembangkan kemampuan memahami teks dan kaitannya dengan pengalaman pribadi, berpikir kritis, dan mengolah kemampuan komunikasi secara kreatif melalui kegiatan menanggapi teks buku bacaan pengayaan dan buku pelajaran. ${ }^{16}$

Untuk mengembangkan pembelajaran berbasis literasi, kurikulum 2013 membuat sejenis tagihan akademik, yakni pada tataran sekolah dasar peserta didik diminta membaca nonteks pelajaran minimal 6 buku, tataran SMP minimal 12 buku, dan tataran SMA/SMK

\footnotetext{
${ }_{16}^{15}$ Kementrian Pendidikan dan Kebudayaan, Kajian dan Pedoman Penguatan Pendidikan Karakter-2016, 29.

${ }^{16}$ Direktorat Jenderal Pendidikan Dasar dan Menengah Kementrian Pendidikan dan Kebudayaan, Desain Induk Gerakan Literasi Sekolah (Jakarta: Direktorat Jenderal Pendidikan Dasar dan Menengah Kementrian Pendidikan dan Kebudayaan, 2016), 22.
} 
minimal 18 buku. ${ }^{17}$ Kegiatan membaca ini bertujuan untuk melatih siswa agar memiliki konsistensi dalam membaca buku, yang nantinya akan menjadi sebuah kebiasaan dan kegemaran.

Program literasi di Sekolah Dasar harus didukung dengan penataan ruang perpustakaan yang nyaman dan menyenangkan. Perpustakaan harus dikelola dengan baik agar mampu meningkatkan minat baca anak SD/MI dan menjadikan mereka pembelajar sepanjang hayat. Perpustakaan SD memiliki peran dalam mengoordinasi pengelolaan sudut baca kelas, area baca dan prasarana literasi lain di SD. Lingkungan sekolah yang mendukung dapat memotivasi siswa untuk giat mengikuti kegiatan sekolah. ${ }^{18}$

Mengacu pada hasil penelitian yang dilakukan oleh Hanin (2019) tentang Pelaksanaan Gerakan Literasi Sekolah dalam Pembentukan karakter Siswa di SDN Madyopuro 2 Malang. Hasil penelitian menunjukkan bahwa pelaksanaan Gerakan literasi sekolah dalam pembentukan karakter siswa memberikan nilai yang positif, diantaranya terbentuknya karakter siswa integritas, religious, disiplin, gemar membaca, dan bertanggung jawab. ${ }^{19}$

Diperkuat lagi penelitian yang dilakukan oleh Erna (2019) yang berjudul "Membangun Karakter Siswa Sekolah Dasar melalui Gerakan Literasi Sekolah”. Hasil penelitian menyatakan bahwa implementasi Gerakan literasi di sekolah dilakukan melalui tahap pembiasaan, pengembangan, dan pembelajaran. Gerakan literasi dilalukan untuk membangun, memperbaiki karakter, dan memberikan dampak positif terhadap generasi bangsa. Melalui pendidikan karakter yang diimplementasikan dalam institusi pendidikan diharapkan degradasi karakter atau moral anak bangsa di masa yang akan datang tidak akan terjadi dan akan terlahir generasi bangsa dengan ketinggian budi pekerti dan karakter. ${ }^{20}$

\section{Kesimpulan}

Anak usia SD/MI merupakan masa transisi dari masa bermain di taman kanak-kanak memasuki lingkungan sekolah formal. Pada masa Sekolah Dasar aspek intelektualitas sudah

\footnotetext{
${ }^{17}$ Dirjen Dikdasmen, Desain Induk Gerakan Literasi Sekolah (Jakarta: Kementerian Pendidikan dan Kebudayaan, 2016), 29-30.

${ }^{18}$ Isnawati Nur Afifah Latif, Optimalisasi Lingkungan Pendidikan di Tengah Pandemi Covid-19, (Premiere, 2020), 5

${ }^{19}$ Nida Helwa Hanin, Pelaksanaan Gerakan Literasi Sekolah di Sekolah Dasar Negeri Madyopuro 2 Malang, (Skripsi, UIN Malang, 2019), 16.

${ }^{20}$ Erna Labudasari, "Membangun Karakter Siswa Sekolah Dasar melalui Gerakan Literasi Sekolah”, (UnMuh Cirebon, 2019), 3.
} 
mulai ditekankan. Karakteristik yang dimiliki pada umumnya baru dapat menerima informasi yang sifatnya konkret ketimbang yang abstrak. Sehingga metode dalam pembelajaran kelas dan metode pembentukan karakter harus dilakukan dengan cara yang menarik dan menyenangkan menyesuaikan karakteristiknya. Hal ini berpengaruh terhadap keberhasilan dalam proses pembelajaran maupun pembentukan karakternya.

Gerakan Literasi Sekolah merupakan suatu usaha atau kegiatan yang sifatnya partisipatif yang melibatkan seluruh warga sekolah. Kegiatan ini pada dasarnya bertujuan untuk menumbuhkan minat baca tulis anak. Meskipun sebenarnya literasi tidak dapat diartikan sempit sebatas kegiatan baca tulis, akan tetapi juga berpikir secara mendalam. Bisa berupa kemampuan dalam menganalisis suatu masalah dan menyampaikan pemikirannya dengan bahasa yang logis, analitis dan sistematis.

Selain bertujuan untuk meningkatkan minat baca tulis anak, program literasi juga membentuk kepribadian anak yang berintegritas sesuai dengan ilmu yang mereka miliki. Membaca buku cerita yang sarat akan nasehat dapat menciptakan kesadaran untuk berbuat baik. Mengerjakan tugas yang diberikan guru juga melatih anak bertanggung jawab atas tugasnya dan menguji tingkat sportivitasnya, apakah mereka jujur saat mengerjakan latihan atau sebaliknya. Dan masih banyak hal strategi dalam gerakan literasi yang dapat merangsang karakter integritas pada anak usia SD/MI

\section{Daftar Referensi}

Chaplin , James P. Kamus Lengkap Psikologi. Jakarta: PT Grafindo Persada. 1993.

Direktorat Jenderal Pendidikan Dasar dan Menengah Kementrian Pendidikan dan Kebudayaan, Desain Induk Gerakan Literasi Sekolah. Jakarta: Direktorat Jenderal Pendidikan Dasar dan Menengah Kementrian Pendidikan dan Kebudayaan. 2016.

Dirjen Dikdasmen, Desain Induk Gerakan Literasi Sekolah. Jakarta: Kementerian Pendidikan dan Kebudayaan. 2016.

Ferguson B., Information Literacy. A Primer for Teachers, Librarians, and Other Informed People (www.bibliotech.us/pdfs/InfoLit.pdf.

Hanin, Nida Helwa. Pelaksanaan Gerakan Literasi Sekolah di Sekolah Dasar Negeri Madyopuro 2 Malang. Skripsi: UIN Malang. 2019. 
Hasan, Said Hamid, dkk., Pengembangan Pendidikan Budaya dan Karakter Bangsa. Jakarta: Puskur Balitbang Kemendiknas, 2010.

Kementrian Pendidikan dan Kebudayaan Republik Indonesia, Kajian dan Pedoman Penguatan Pendidikan Karakter.

Kementrian Pendidikan Nasional, Bahan Pelatihan, Penguatan Metodologi Pembelajaran Berdasarkan Nilai-nilai Budaya untuk Membentuk Daya Saing dan Karakter Bangsa. Jakarta: Kementrian Pendidikan Nasional, 2010.

Labudasari, Erna. Membangun Karakter Siswa Sekolah Dasar melalui Gerakan Literasi Sekolah”. UnMuh Cirebon. 2019.

Latif, Isnawati Nur Afifah, Optimalisasi Lingkungan Pendidikan di Tengah Pandemi Covid-19, PREMIERE : Journal of Islamic Elementary Education, 2(1), 43-62, DOI: https://doi.org/10.51675/jp.v2i1.86, 2020.

McCain, John \& Mark Salter, Karakter-Karakter yang Menggugah Dunia, Terj. T. Hermaya. Jakarta: Gramedia Pustaka Utama, 2009.

Pradana, Akhmad Aji \& Jazilatul Ummah, PENGARUH MEDIA SEMPOA TERHADAP KEMAMPUAN OPERASI HITUNG PENGURANGAN SISWA KELAS II MI . PREMIERE : Journal of Islamic Elementary Education, 2(1), 94-102. https://doi.org/10.51675/jp.v2i1.89, 2020

Prawiro, M., "Arti Integritas Diri: Pengertian, Fungsi, Manfaat dan Urgensinya", www.maxmanroe.com/vid/umum/arti-integritas-adalah.html, dikases 1 Juni 2021.

Prawiro, M, Kamus Besar Bahasa Indonesia (KBBI) online, www.maxmanroe.com/vid/umum/arti-integritas-adalah.html. Lihat juga pada http://kbbi.web.id/integritas.html, dikases 1 Juni 2021.

Suyono, Pengembangan Perilaku Berliterasi Siswa Berbasis Kegiatan Ilmiah: Hasil-hasil Penelitian dan Implementasinya di Sekolah, Jurnal Ilmu Pendidikan, Jilid 3, Nomor 2, Juni 2006 